2015

\title{
The Oxford Handbook of Caribbean Archaeology
}

Frederick H. Smith

College of William and Mary

Follow this and additional works at: https://scholarworks.wm.edu/aspubs

\section{Recommended Citation}

Smith, F. H. (2015). The Oxford Handbook of Caribbean Archaeology, edited by William F. Keegan, Corinne L. Hofman \& Reniel Rodríguez Ramos. New West Indian Guide/Nieuwe West-Indische Gids, 89(3-4), 427-428.

This Article is brought to you for free and open access by the Arts and Sciences at W\&M ScholarWorks. It has been accepted for inclusion in Arts \& Sciences Articles by an authorized administrator of W\&M ScholarWorks. For more information, please contact scholarworks@wm.edu. 


\section{William F. Keegan, Corinne L. Hofman \& Reniel Rodríguez Ramos (eds.)}

The Oxford Handbook of Caribbean Archaeology. Oxford: Oxford University Press, 2013. $\mathrm{xx}+594 \mathrm{pp}$. (Cloth Us\$150.00)

This volume represents the most comprehensive collection to date of current Caribbean archaeological studies. The 38 essays address nearly every key archaeological issue concerning the human settlement of the Caribbean region and the development of Caribbean societies from the initial peopling of the region some 6000 years ago to European colonization and plantation slavery after 1492. Drawing on a wide range of evidence, including ethnohistorical, bioarchaeological, environmental, paleobotanical, linguistic, faunal, and various other specialized forms of analysis, they shed new light on seafaring, migration, kinship, religion, conflict, exchange and many other themes that have come to define human interaction in the Caribbean, untangling the complexity of Caribbean societies in the process.

In the introduction, the editors offer a general overview of Caribbean archaeology. They make a case for the Caribbean as a distinct cultural area and challenge traditional unilinear evolutionary models for understanding the emergence of Caribbean societies. The first of the book's five sections then begins with an insightful essay by Peter E. Siegel that outlines the historical and intellectual climate in which Caribbean archaeology developed. From the midnineteenth century to the 196os, the work followed general trajectories in world archaeology, providing descriptive studies and classificatory schemes for prehistoric peoples in the region. Reviewing papers from the International Association of Caribbean Archaeology meetings since the 196os, Siegel showcases the shift from a simple descriptive endeavor to a professional field of research embracing a diverse range of scientific and humanistic approaches. Next, Jago Cooper provides a useful analysis of Caribbean climate change and its role in shaping human migration and development in the Caribbean.

The second section, which explores ethnohistorical evidence, will be of great interest, not only to Caribbean archaeologists, but also historians seeking to understand the diversity and complexity of Caribbean peoples at the time of European contact. Julian Granberry traces the languages of various groups at the time of contact to migrations from various South and Central American homelands. William Keegan's thoughtful essay blends documentary evidence from Spanish chroniclers with archaeological assemblages from Hispaniola, Puerto Rico, and Cuba to understand "Classic" Taino kinship, social organization, and mythology. Keegan seeks to challenge simplistic evolutionary models of Taino kinship and, instead, highlight the fluidity of Taino social organization in the centuries before European contact. Bradley E. Ensor draws on settlement

(C) FREDERICK H. SMITH, 2015 | DOI: 10.1163/22134360-08903050

This is an open access article distributed under the terms of the Creative Commons 
layout evidence to support the somewhat variable nature of Taino kinship, and Louis Allaire's wonderful essay reviews documentary and archaeological evidence to deconstruct the origins and identity of the Island Carib.

The third section focuses on the peopling of the Caribbean, highlighting migration, cultural diversity, interaction, and exchange in the islands, challenging traditional culture history models in the region. A provocative essay by Michael Heckenberger, for example, problematizes the notion of an Arawak Diaspora, using the term Diaspora to emphasize cultural fluidity in Amazonia, the homeland of the Saladoid (the Taino ancestors). He focuses on the internal and external socio-political forces shaping the movement of Amazonian peoples into the Caribbean, as well as the efforts of these tropical agriculturalists to adapt to a new insular environment. Benoît Bérard defines the material world and settlement patterns of Saladoid peoples in the Caribbean and outlines their connections with mainland Arawakan traditions. Corinne L. Hofman's important essay examines the social and environmental forces that shaped the development of Saladoid peoples after centuries in the Lesser Antilles.

The fourth section is an assortment of theoretically driven essays and methodological overviews covering seafaring, exchange networks, diet, mortuary practices, rock art, and other aspects of Caribbean prehistory. Joshua M. Torres focuses on agency and community networks for explaining the rise of chiefdoms in the Greater Antilles. Alice V.M. Samson stresses the need for household archaeology in Caribbean prehistory. Susan D. deFrance's faunal studies, Jaime R. Pagán-Jiménez's plant studies, and William J. Pestle's stable isotope analysis provide insights into the structure of prehistoric Caribbean diets.

The final section covers historical archaeology and the political legacy of Caribbean archaeological work. Douglas V. Armstrong offers a comprehensive analysis of historical archaeological studies in the Caribbean, stressing research on plantation slavery in the region, and showing that the archaeology of slavery and plantation life in the Caribbean can contribute more broadly to the study of social inequality, labor, race, and resistance in plantation settings throughout the Americas. And E. Kofi Agorsah highlights the archaeology of maroon communities within the context of freedom and resistance to colonial dominion.

This excellent volume covers key themes in Caribbean archaeology and is a must read for archaeologists working in the region. It will no doubt serve as an important reference for future Caribbean archaeologists.

\section{Frederick H. Smith}

Department of Anthropology, College of William and Mary,

Williamsburg vA 23187 , U.S.A.

fhsmit@wm.edu 